\begin{tabular}{|l|l|c|l|}
\hline Eiszeitalter u. Gegenwart & $\mathbf{4 7}$ & $\begin{array}{c}120-128 \\
6 \text { Figures }\end{array}$ & Hannover 1997 \\
\hline
\end{tabular}

\title{
Problems of landslide chronology in the Mátra mountains in Hungary
}

\author{
Jósef SZABó* \& ENIKÓ FÉLEgYHȦZI* \\ Landslide processes, pollendiagrams, radiocarbon dating, Holocene, Hungary
}

\begin{abstract}
A detailed survey and mapping of the landslide processes and surface forms in the volcanic middle mountains of Hungary formed in the Middle and Late Miocene was carried out in the past decade. As a result of investigations it can be stated that thier occurrence is mainly confined to the areas as follows:

a) marginal zones of volcanic mountains,

b) steep inner slopes of the former calderas of eruption,

c) valley slopes cut into stratovolcanic structures.

In their characteristic regions of occurrence landslide forms are important, in some places even determinant components of morphology. The overwhelming majority of the landforms are no more active and can be considered fossilised. Consequently, landslide processes used to play a significant role in forming slope morphology in previous stages of geomorphic evolution. Research performed heretofore has provided only rather ambiguous answer to the question concerning the time of emergence of landslides on a theoretical basis
\end{abstract}

Due to the absence of young sediments traditional stratigraphic methods could not yield satisfactory results. The authors therefore attempted to determine the time of the upfilling of lakes or bogs located in undrained depressions dammed by slides and the minimum age of the landslides through the analyses of borehole samples. In the Matra sediments upfilling of 7 such depressions were carried out. In several cases pollen diagrams were obtained and in two boreholes radiocarbon dating of samples were performed. The paper summarises the results of the borehole analyses and evaluates pollen records supported by $\mathrm{C}^{14}$ dating in detail.

Analyses performed using various methods indicate a beginning of the bog formation in the Early Holocene, consequently landslides occurred presumably in the wake of the Preboreal or prior to that in a warm spell following the Late Glacial.

Although these results cannot be extrapolated to all the landslides identified in the two mountains (their number is ca. 20) without more ado nevertheless they are orientating.

\section{[Rutschungschronologische Fragen im Matra-Gebirge in Ungarn]}

Kurzfassung: Im letzten Jahrzehnt wurden bei der Untersuchung der Rutschungsprozesse und -formen in Ungarn in den Mittelgebirgen, die zumeist in der Mitte und am Ende des Miozäns entstanden sind, viele Rutschungsformen

\footnotetext{
*) Adresses of the authors: Dr. J. Szabó, Dr. E. FélegyhàzI, Department of Physical Geography, Lajos Kossuth University, Debrecen, Hungary
}

aufgenommen. Als Ergebnis der Geländeuntersuchungen kann festgestellt werden, daß diese Formen vor allem auf folgenden Gebieten vorkommen:

a) in der Randzone der vulkanischen Gebirge,

b) auf der steilen inneren Seite der Calderen der ehemaligen Ausbruchszentren,

c) auf den Hängen der die schichtvulkanischen Strukturen tief ein- oder durchschneidenden Tälern.

In den erwähnten charakteristischen Vorkommensbereichen stellen die Rutschungsformen einen wichtigen, an manchen Stellen einen entscheidenden Faktor des morphologischen Bildes dar. Die überwiegende Mehrheit der Formen ist heute nicht mehr aktiv, und die meisten von ihnen kann als fossil betrachtet werden. Deshalb ist es offensichtlich, daß die Rutschungsprozesse in der früheren Periode (oder in den früheren Perioden) eine wichtige Rolle in der Gestaltung der Form der Hänge spielten. Die bisherigen Forschungen gaben nur eine ziemlich unsichere, bloß prinzipielle Antwort auf die Frage nach der Entstehungszeit der Formen.

Da die jungen Sedimente fehlen, konnte durch die gewöhnlichen stratigraphischen Methoden kein gutes Ergebnis erzielt werden, deshalb versuchten die Verfasser durch Bohrungen in den geschlossenen, abflußlosen - mit einem See oder Moor ausgefüllten - Eintiefungen der größeren Rutschungen die Aufschüttungsdauer der Eintiefungen, und dadurch das minimale Alter der Rutschungen zu bestimmen. Im Mátra-Gebirge wurde das Auffüllungsmaterial der Rutschungseintiefung untersucht. In manchen Fällen konnte eine Pollenanalyse durchgeführt werden, in zwei Bohrungen kam es auch zu einer ${ }^{14} \mathrm{C}$-Altersbestimmung. In der vorliegenden Studie werden die Ergebnisse der Bohrungen zusammengefaßst, und ausführlich werden die auch durch die ${ }^{14} \mathrm{C}$-Altersbestimmung unterstützten Pollendiagramme interpretiert.

Die mit den verschiedenen Methoden durchgeführten Analysen zeigen, daß die Moorbildung in den untersuchten Fällen in der ersten Periode des Holozäns begann, und die Rutschungen erfolgten wahrscheinlich am Anfang der präborealen Zeit, oder früher, während einer Klimaverbesserung nach irgendeiner Kaltperiode der Spätglazialzeit. Die erhaltenen Ergebnisse können wohl auf die anderen - insgesamt etwa 20 - Rutschungsformen nicht extrapoliert werden, aber sie stellen doch eine Orientierungshilfe im Bezug auf ihr Alter dar.

\section{Introduction}

A detailed survey and mapping of the landslide surface forms in the volcanic middle mountains of Hungary was started in the past decade. Geomorpholo- 
gists studying volcanic ridges previously either did not pay particular attention to features of slumping or considered them insignificant additional morphological elements of the landscape. In our earlier papers (SZABó J. 1992, 1993) short preliminary reports were presented on the results of field works elucidating the high importance of the part played by landslide processes in the geomorphic evolution in several regions of the Tertiary volcanic mountains (notably the Visegrád Mountains, the Mátra Mountains and the basalt volcanos north of Lake Balaton) where slumps are essential, in some cases even determinant components of the morphology. Their occurrence is mainly confined to the areas as follows:

a) marginal zones of volcanic mountains,

b) steep inner slopes of the former calderas of eruption,

c) valley slopes cut into stratovolcanic structures.

a) This is the most frequent case. Where the bed of loose material underlying the extrusive or loose volcanic matter is still on the surface as for exemple in the mountain margins, and is probably situated higher than ist surroundings, it has lost stability under the weight of the volcanic layers and functions as sliding plane for volcanites on a sufficiently high and steep slope. The bed underlying acid and neutral volcanites formed in the Badenian stage of the Miocene is usually the schlieren of the Carpathian stage (or occasionally oligocene sediment) while basalts of the late Miocene generally overlie sandyclayey Pannonian deposits. The probability of landslides was enhanced by a (sometimes asymmetric) uplift of the volcanic margin, such increasing the elevation over the surrounding area. Sliding planes could develop within the volcanic sequence. It was made possible by the stratovolcanic structure for slides could occur along the surface of loose tuff horizons especially if the latter was increasingly weathered. On the northern slopes of the Mátra crest the geomorphic evolution and the tectonic structure created favourable conditions for landslides so a frequent series of slumps can be observed on the slopes. In spite of the spatial discontinuity the major forms of slumping make up a distinct (maximum $1 \mathrm{~km}$ wide) zone of slides, differing morphologically from the foothills of the mountains dissected by valleys.

b) The previous centres of eruption have survived in remnants only. (So. e.g. the more or less intact parts of the double caldera in the Visegrád Mountains has slumped in several places along the steep inner side and at the base of the caldera walls a series of huge displaced blocks can be found.)

c) The slumps occurring on the slopes of valleys dissecting the inner portions of the volcanic ridges are as a rule slides along the tuff layers cut during incision. If the whole volcanic sequence had been cut in valley evolution the underlying bed of volcanites could serve as sliding plane. The majority of the landslide forms are stable and are in a stage of degradation. Active parts still in motion occur sporadically and are of insignificant size as compared to the earlier slides. Consequently, these landslide forms of natural origin have relevance primarily not to the prensent-day surface dynamics but being remnants of intensive past processes they are indispensable for the understanding of the morphology in the concerned zones of volcanic ridges.

The majority of the mapped landforms are much more older than to be dated directly (on the basis of historical records, written documents or maps, perhaps by the deformed growth of trees). At the same time they are much younger than the cover on them or in their immediate surroundings (in the studied areas no loess series that might have been relevant to dating were found) so the traditional stratigraphic methods of age determination could not be used. Consequently, dating of the landslide events has been carried out on a general theoretical basis (e.g. by founding periods of climates favourable for the development of landslides) and was highly ambiguous. A final and general solution of this problem necessitates further and substantial investigations on landslides and the present paper reports on the initial efforts which might contribute to a more exact dating of occurrence of particular slumps. Extrapolation of these results is to be carried out by due cautiousness.

\section{Principles, range and methods of investigations}

The determination of the relative age of landslide forms and an approximation of their absolute age are made possible by the analysis of their degradation (transformation). Degradation has well recognisable distinct phases. Among them especially important are the characteristic trends of development of depressions formed through damming by the slumped masses. These depressions have basically two different ways of evolution.

1. Their closed (undrained) character might be altered by a complete upfilling. In this case after certain period only rounded steps remain on the place of depressions.

2. Closed depressions can be eliminated through drainage. Following landslide events water provided by springs at various levels of the failure surface fills up the depression and (depending on the degress of recharge) is overflowing its edge gradually cuts it and opens the basin (certainly water of the springs can play an important role in the upfilling of the depression). Chances for the discharge are even better when this basin is formed in the upper section of the 
A

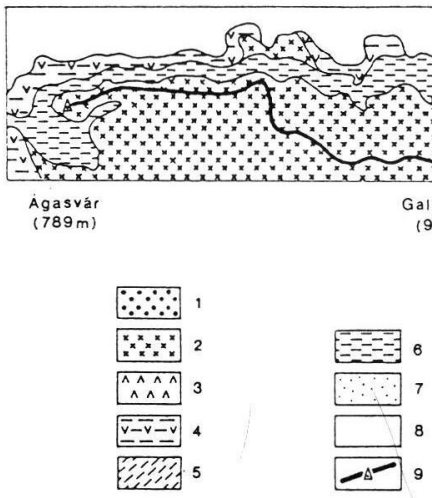

B
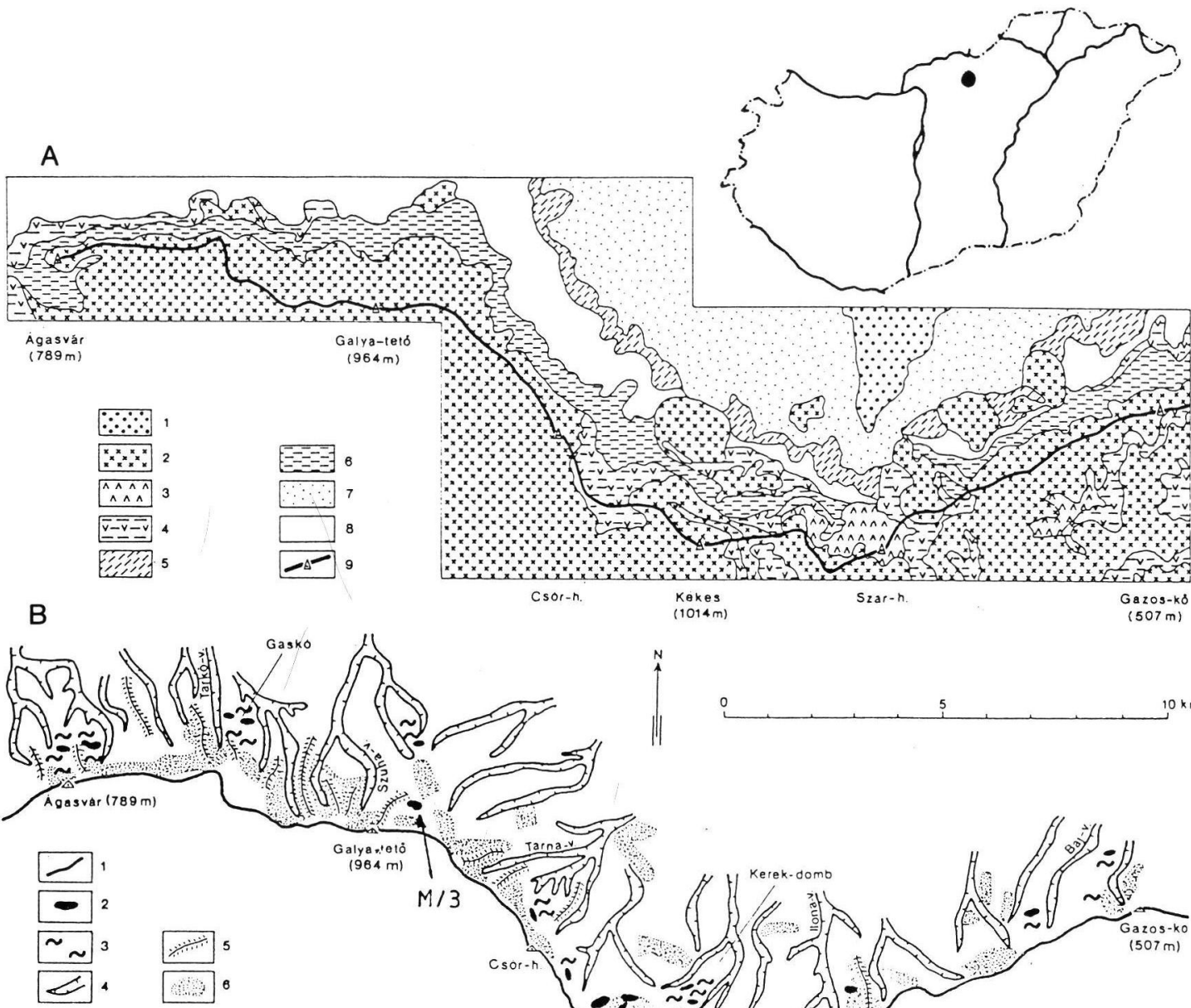

$\begin{array}{ll}\text { Csor-h. Kekes } & \text { (1014m) }\end{array}$

Szar-h
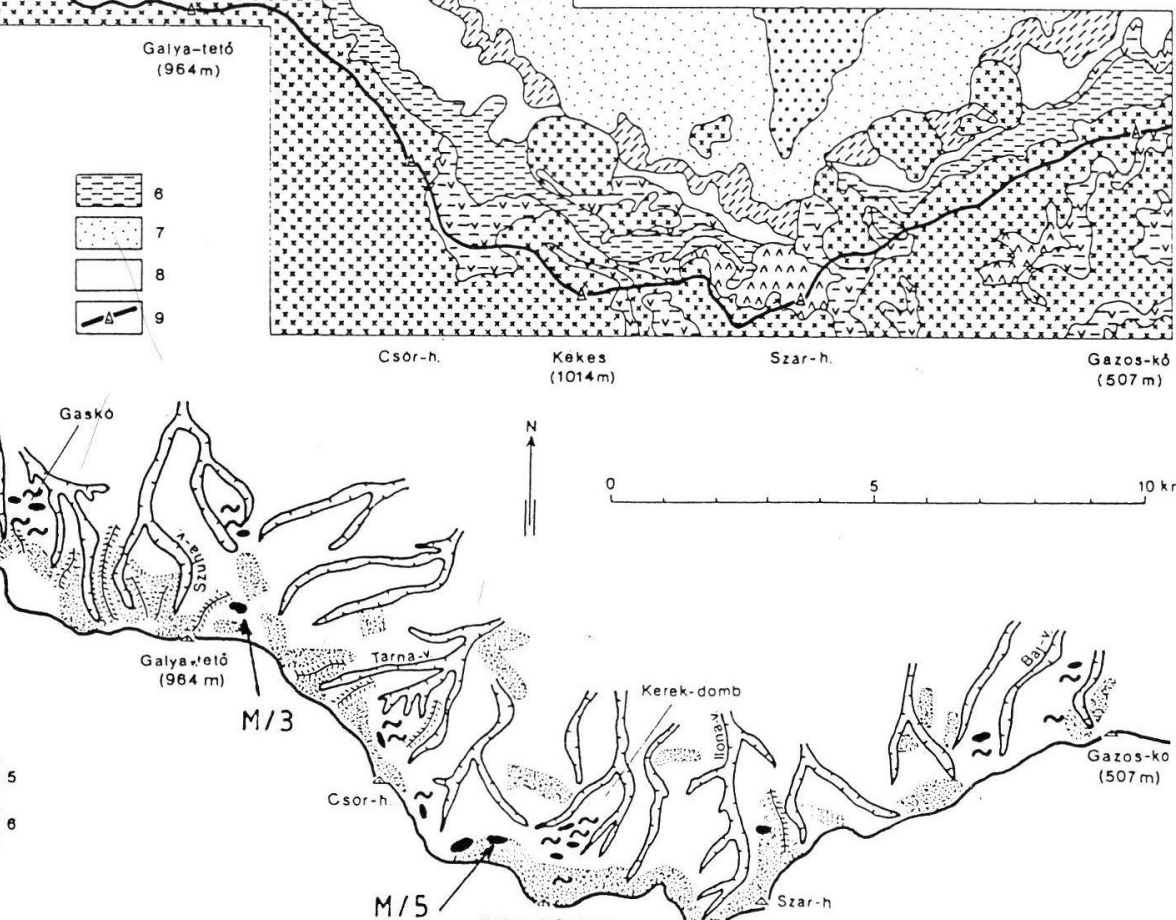

5 $10 \mathrm{~km}$

Fig. 1: Geological form
Szabó J. and DÁvid L.)

A/ 1= Eocene biotite-amphiboleandesite,2= Karpatian-Badenian andesites, $3=$ Badenian pyroxene-andesite lava agglomerate, 4= Karpatian-Badenian pyroxeneandesite-tuff agglomerate, 5= Ottnangian-Karpatian „lower rhyolite tuff“, 6= Badenian dacitic rhyolite tuff, $7=$ Oligocene sandstone, clay marl, $8=$ lower and middle aleurite(schlieren), partly sandstone, $9=$ main crest of the Mátra Mountains

B/ 1 = main crest of the Mátra Mountains, 2= closed depression dammed by slide usually occupied by lake or bog, $3=$ uneven surface of slump heaps or blocks, $4=$ erosional valleys, $5=$ rock formations branching from the main crest with steplike slopes, $6=$ slopes steeper than $20^{\circ}$

Abb. 1: Geologische Bildungen und geomorphologische Skizze entlang dem Hauptgrat des Mátra Gebirges (nach der geologischen Karte von Ungarn - 1:200.000. konstruierten Szabó, J. und DÁvid, L.)

A, 1= Eozäne Biotit- und Amphibolandesite, 2= Karpatische und Badenische Andesite (Miozän), 3= Lavaagglomeratum aus Piroxenandesit (Badenisch), 4= Tuff und Agglomeratum (Karpatische, Badenische Piroxenandesit), 5= „Untere Rhyolittuff“ (Ottnangisch-Karpatisch), $6=$ Dazitartige Riolittuff (Badenisch), $7=$ Sandstein und Tonmergel (Oligozän), 8= Untere- und mittlere Schlier (teilweise Sandstein), 9= Hauptgrat des Gebirges.

B., 1= Hauptgrat des Gebirges, 2= abgeschlossene Depressionen (im allgemeinen mit Teich oder Moor), 3= unebene Oberfläche der abgerutschten Massen, 4= Erosionstäler, 5= stufenförmige seitliche Felsengrate des Hauptgrates, $6=$ Hänge ( $>20$ Grad).

slope due to the high erosional energy of the overflowing water.

In most cases the activities of springs create a lake in the depression. Once recharge of the lake is slowing down or ist upfilling reaches an advanced stage the vegetation develops rapidly and a bog appears. This bog may exist for a relatively long time though its natural development might be interrupted or terminated by the arrival of a substantial amount of unorganic sediments (provided by a subsequent slump or surface erosion) or by desiccation due to the stoppage of recharge. 


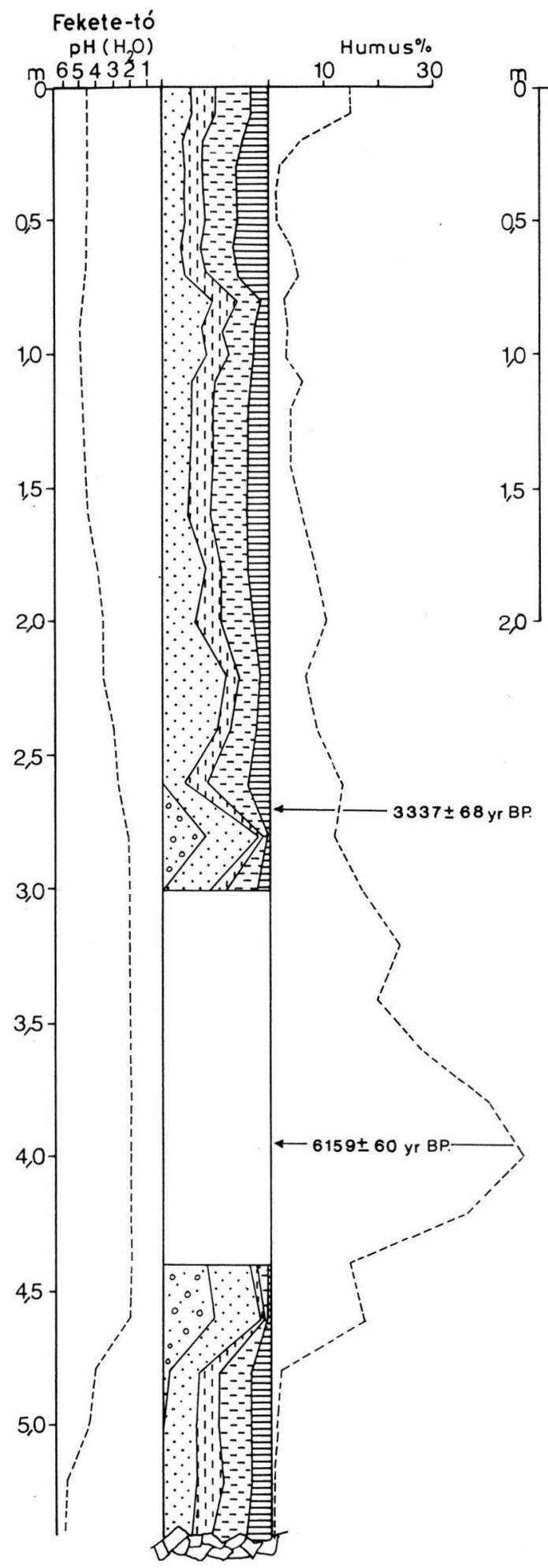

Köris mocsár

$\mathrm{pH}(\mathrm{HO})$

654321

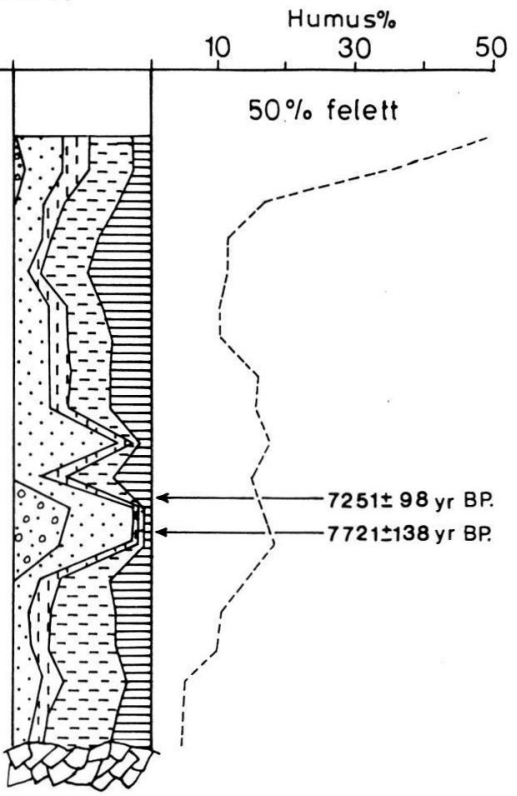

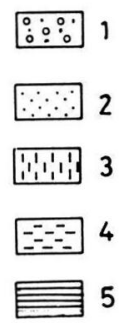

Fig. 2: Profile of the boreholes $M / 3$ (Fekete Lake) and M/5 (Köris Bog) in the Mátra Mountains. For the borehole sites see Fig $1 / \mathrm{B} 1=$ sand with small gravel, $2=$ sand, $3=$ silt, $4=$ mud, $5=$ clay (blank stripes within the columns correspond to places where granulometric analysis is not feasible due to the presence of plant residue)

Abb. 2: Bohrungsprofile (M/3=Fekete-See, M/5= Köris Sumpf). Lage der Bohrungen in Abb. 1/B.

1= Sand mit feinkörnigen Kies, $2=$ Sand, $3=$ Staub, $4=$ Schlamm, $5=$ Ton (in den leeren Teilen der Profile die Kornzusammensetzung wegen der torfigen Pflanzenreste nicht prüfbar) 

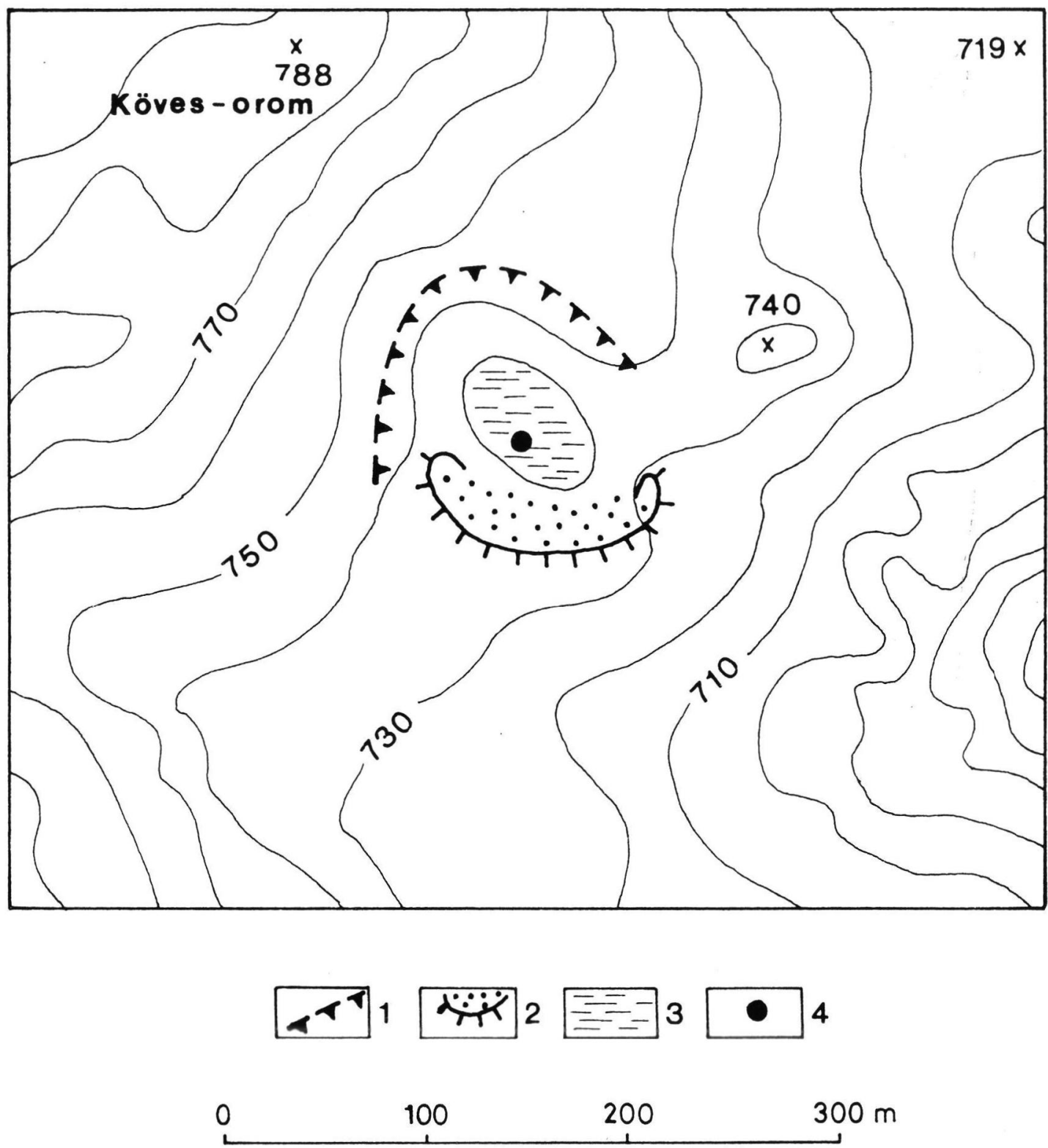

Fig. 3: Surroundings of the Fekete Lake slide (Mátra Mountains) $1=$ failure front, $2=$ slumped down mass, $3=$ lake, $4=$ site of the borehole

Abb. 3: Die Umgebung der Rutschung „Fekete See“

$1=$ Hauptabrißwand, $2=$ abgerutschte Masse, $3=$ See, $4=$ Bohrung (M/3). Höhen in $\mathrm{m}$ über dem Meeresspiegel.

To unfold details of the above mentioned processes and to determine an approximate age of slumps boreholes were drilled in closed depressions (filled with lakes, bogs or ones already upfilled and dry) found in volcanic ridges. 7 holes in the Mátra were drilled down to max. $6.5 \mathrm{~m}$ depth.

In all but 2 cases they reached the surface of a relatively hard volcanic rock (mostly tuff). Pure but not undisturbed samples were collected through
$10-20 \mathrm{~cm}$ for the subsequent analyses. Granulometric composition, humus and calcium carbonate content and $\mathrm{pH}$ were determined. Palynological analysis was carried out in each samples. Absolute dating of vegetation remnants of some layers from two boresholes i. e. ${ }^{14} \mathrm{C}$ investigations were performed by Ede Hertelendi in the Radiocarbon Laboratory of the Institute of Nuclear Physics (Debrecen). 


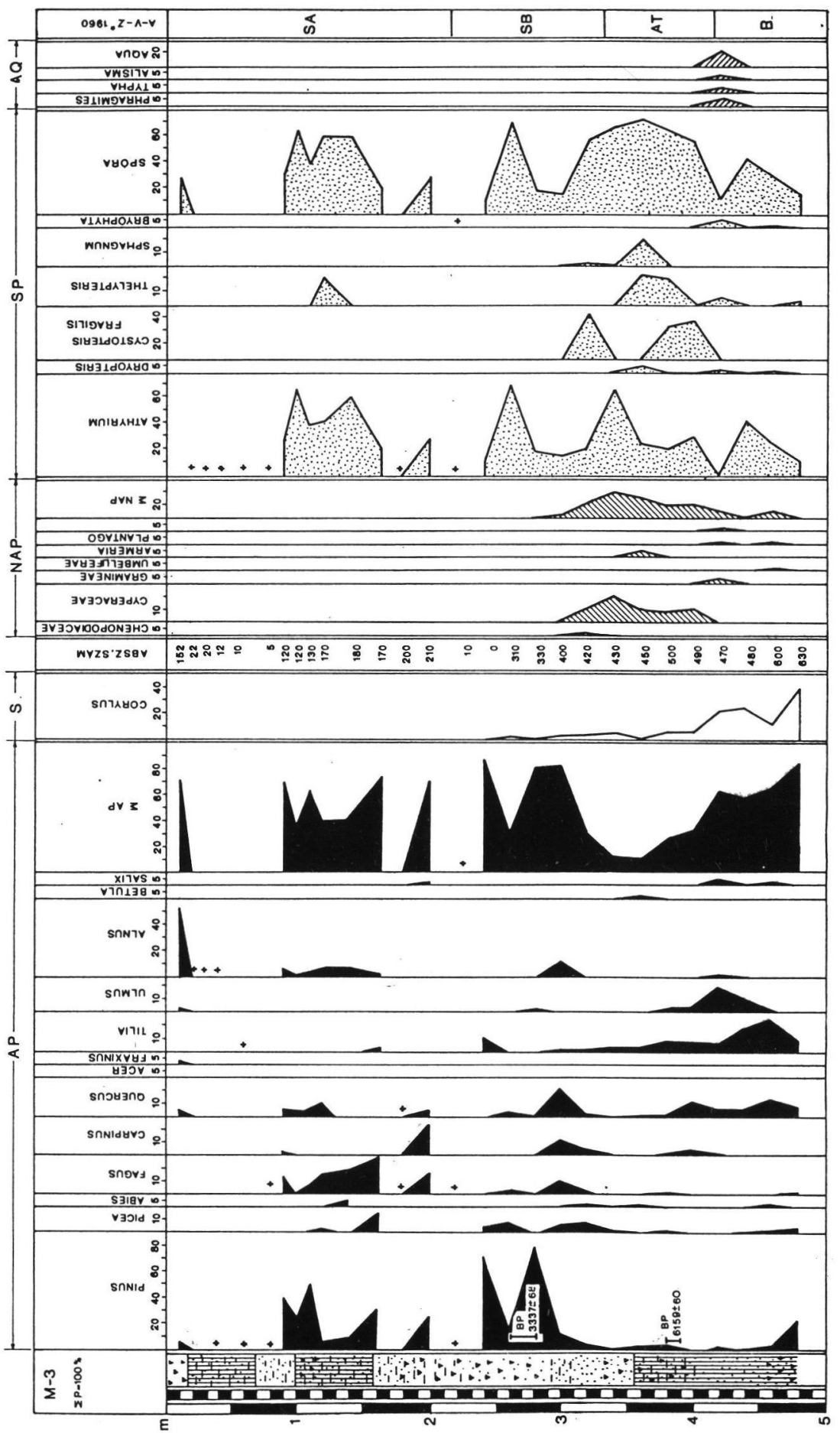

Fig. 4: Pollen diagram of the bottom sediments of the Fekete Lake (Matra Mountains), as a percentage of the total amount of spores/pollen. For the boreholesite $(\mathrm{M} / 3)$ see Fig.1/B. $1=$ clay, $2=$ mud, $3=$ sand, $4=$ debris, $5=$ peat, plant residue. Absolute time scale by Andersen-de Vries-Zagwijn (1960)

Abb. 4: Pollendiagramm der Bohrung „Fekete See“ (M/3). Pollenzahl in Prozent der Gesamtpollensumme (Spora/Pollen). Die Lage der Bohrung in Abb. 1/B. 1= Ton, 2= Schlamm, 3= Sand, 4= Schutt, 5= Torf, Pflanzenreste. Absolute Chronologie nach Andersen - de Vries - Zagwijn (1960) 


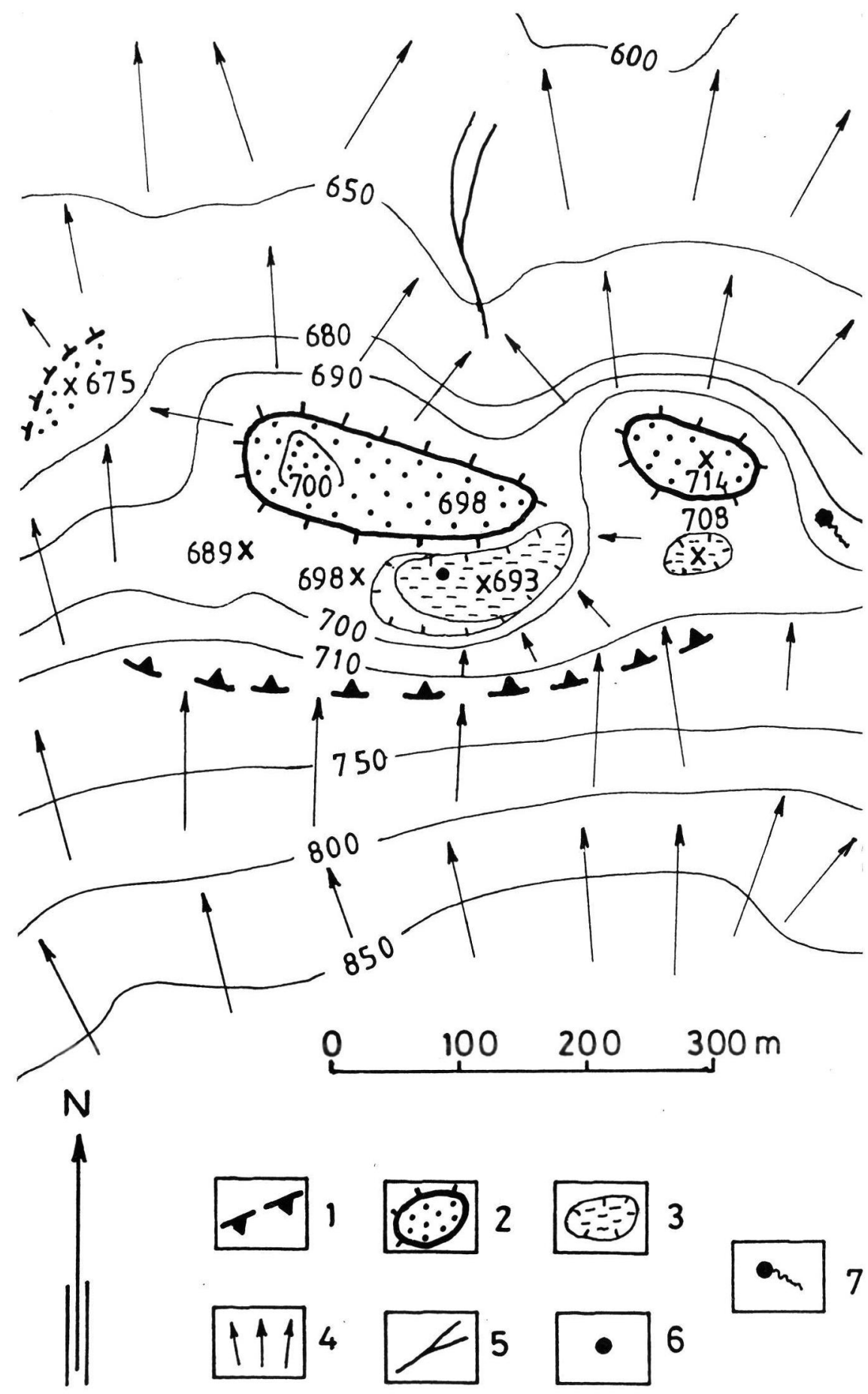

Fig. 5: Landslite of the Köris Bog (Mátra Mountains) and its surroundings (altitudes a.s.l. in metres) 1= approximate position of the main failure front, $2=$ heap of the slumped down mass, $3=$ closed depression dammed by slide (with the lake), $4=$ general sloping direction, $5=$ erosional trench with bog, $6=$ site of the borehole, $7=$ spring

Abb. 5: Rutschung „Köris Sumpf“ und ihre Umgebung = Höhen in m über dem Meeresspiegel)

1= Annähernde Lage der Hauptabrißwand, 2= abgerutschte Massen, $3=$ abgeschlossene Depression (mit Teich), 4= allgemeine Hangrichtungen, $5=$ Eorosionsgraben, $6=$ Bohrung $(M / 5), 7=$ Quelle 


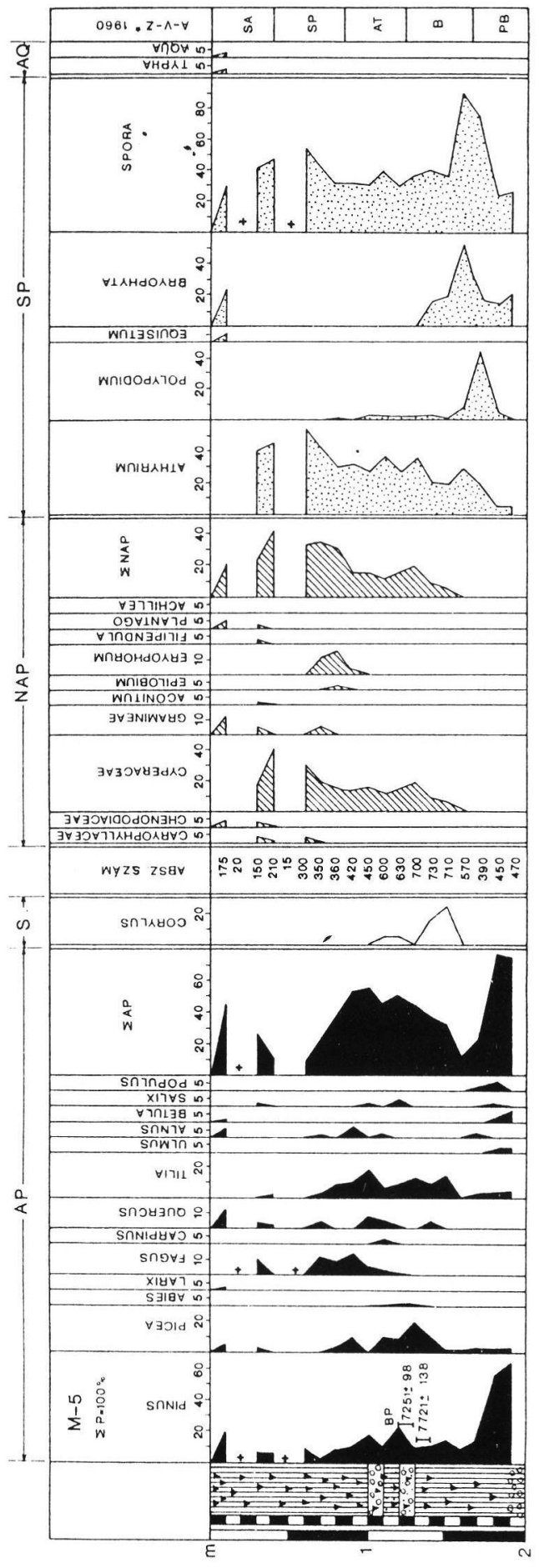

Fig. 6: Pollen diagram of the sediments of the Köris Bog (Mátra Mountains) as a percentage of the total amount of spores/pollen. For the borehole site $(M / 5)$ see Fig. $1 / B$.

Abb. 6: Pollendiagramm der Bohrung "Köris Sumpf" (M/5). Pollenzahl in Prozent der Gesamtpollensumme (Spora/Pollen) - Zeichen in Abb. 4. Die Lage der Bohrung in Abb. 1/B.

\section{Discussion}

\section{Landslides in the Mátra Mountains}

The overwhelming majority of landslides found here are resulted from the stratovolcanic structure of the ridge, the presence of primary volcanic forms (calderas, lava fields) the slope conditions brought about by subsequent tectonic movements and the specific character of the contact of the volanic sequence with the less consolidated underlying bed (SZABÓ J. 1991, 1992, 1993, DAVID L. 1992). Most of them have developed on the steep northern side of the mountain crest (Fig. 1). The western part of the crest from Agasvár to the Piszkés-tetö and it eastern portion with the Kékes group to the Tarna Valley are the margins of the remnants of a volcanic klippe with a steep northern slope. Its central part, however (between the Piszkés-teto and the Kékes) is a fragment of the tectonically disturbed outer side of a caldera steeply sloping northward (SzÉKelY A. 1983, 1987). During the landslides pyroxene-andesite lava, agglomerate and tuff (partly dacitic rhyolite tuff) were moving on the unconsolidated bed underlying the volcanites, generally on Lower and Middle Miocene aleurolite (in some cases weathered tuff layers) as sliding plane. Already fossilised forms of landslides along the northern side of the Mátra crest make up a discontinuous zone with distinct morphological features. In the 7 selected depressions dammed by slumps two boreholes (M/3, $\mathrm{M} / 5$, Fig.2) provided profiles perspective for dating.

\section{Fekete Lake}

The basin of the Fekete Lake located on the eastern flank of the Galya-tetö at an altitude $731 \mathrm{~m}$ a.s.l. was created by a single rhyme of a large-scale rockslide (Fig. 3). Based on the studies of the exposed failure front and the nearby road cut the sliding plane was heavily weathered dacitic rhyolite tuff. According to the information gained from the borehole $(\mathrm{M} / 3)$ drilled in the depression with a diameter of $100 \mathrm{~m}$ the evolution of the lake can be summarised as follows (Fig. 4).

In the depression dammed by the slide a dystrophic lake $(\mathrm{pH}=5)$ rich in humus with low carbonate and nutrient content developed more than 9.000 years ago under cool and moist climate. At that time in the vicinity a mixed grove forest (linden and conifers with hazel in the bush level) existed. With the gradual upfilling of the lake by the end of the Boreal phase in the coastal zone bulrush (Typha) and reed (Phragmites) appeared, then with the advancement of moss and fern the lake started to turn into bog. It became a typical swelling bog in the Atlantic phase indicated by an enrichment in spores of acidophilous mosses, especially Sphagnum species, those of the sedge family (Cyperaceae) and ferns (Athyrium,Cystopteris, Dryopteris). The above age has been confirmed by a radiocarbon dating of $6,159 \pm 60 \mathrm{yr}$ for the 
horizon between 4.2 and $4.4 \mathrm{~m}$. In this phase there was a relative decrease in the share of the arboreal pollen for it was a swelling bog with no trees. Presently this type is very characteristic under moist oceanic climate (ombrogenic bog). In the following phase the reduced amount or the temporary disappearance of beech (Fagus) and hornbeam (Carpinus) indicate a change in climate with drier summers and increased continental influence. According to ${ }^{14} \mathrm{C}$ dating this occured 3.300 years ago i.e. in the subboreal phase. Aridisation of summers resulted in the appearance of pine (Pinus silvestris) and in the emergence of a pine-bog. During this dry phase the pollen containing ability of the accumulating sediments became heavily reduced and only the most resistant spores and pollen survived in low quantity not suitable for analysis. The advancement of pine is documented in other regions, too: e.g. E. KRIPPEL (1986) carrying out stratigraphic analyses of the bogs in Slovakia pointed on a similar phenomenon having taken place in the subboreal phase. Drier and moister spells were alternating in the Subatlantic phase. The plant cover in the vicinity was represented by hornbeam-beech forests. The bog was settled by alder (Alnus) and a slightly acidic ( $\mathrm{pH}=5-6)$ dystrophic bog developed. Climates in the Subatlantic created favourable conditions for the climax of the submontane beech forests. Fekete Lake is still situated in the submontane beech woodland zone with alder grove forests, oak and elm.

Based on the above records on the bog development the landslide is assumed to have occurred in the wake of the Preboreal phase or even earlier, during the improvement of the climate subsequent to a cold spell of the Late Glacial.

\section{Köris Bog}

Its basin is situated at an altitude ( $705 \mathrm{~m}$ a.s.l.) similar to that of the Fekete Lake, and the forming landslide by the prensent morphological features (Fig. 5.) occurred in an main single phase. The deep sliding plane of the slide was probably a weathered pyroxeneandesite tuff but it might have been the unconsolidated underlying bed of volcanites. The landslide of the Köris Bog forms an organic part of the landslide zone flanking the northern crest of the Mátra Mountains. Its dating was based on the analyses of the $(\mathrm{M} / 5)$ borehole profile (Fig. 6).

Pollen record shows a dominant coniferous forest with deciduous species during the deposition of the lowermost horizon. Pine (Pinus silvestris) and spruce (Picea) were associated with some elm (Ulmus) and linden (Tilia). This vegetation was characteristic for the late Preboreal. Abundant atmospheric precipitation created favourable conditions for the emergence of ombrogenic bogs. On the acidic debris a dystrophic bog developed poor in carbonates and nutrients with acidophilous bryum and fern. It developed into a swelling bog in the Boreal. In this phase the conifers were retreating from the surroundings and a deci- duous forest emerged with linden, elm, oak and hazel in the shrub level. Radiocarbon analyses of these horizons $(7.250$ and $7.720 \mathrm{yr}$ ) seem to corroborate results of the palynological analysis (Fig. 6). The rate of sedimentation slowed down in the Atlantic (from an earlier $40 \mathrm{~cm}$ to $20 \mathrm{~cm}$ per $1000 \mathrm{yr}$ ). The reason might have been that the peat-bog had turned into a moist boggy meadow of sedge vegetation surrounded by high stalk. With the emergence of grass (Gramineae) a bog meadow started to develop. The Subboreal was dominated by beach, hornbeam, oak and linden. Increasing continentality in climate can be documented with the drop in the share of beech pollen and by the disappearance of hornbeam. In the Subatlantic the high sedge meadow survived which (after a recurring aridisation) was characterised by the enrichment of paludal elements. Also this is the present-day situation. Pollen of Larix already indicates coniferous plantations.

On the basis of the bog development the occurrence of the landslide (similar to that of the Fekete Lake) can be put to the Early Holocene or to a transitional spell from the Late Glacial to the Preboreal.

\section{Conclusions}

First detailed studies on the time of the occurrence of landslides in the volcanic ridges of Hungary $\mathrm{C}^{14}$ datings point out 8.000 to $10.000 \mathrm{yr}$ B.P. as a minimum age of landslides. Theoretically they might even be older but the fact that paludal sediments of the Köris Bog immediately overlie the rock debris of the slump seems to limit the age of this phenomenon. Though these results cannot be extrapolated to all the fossil landslides identified in the mountains (their number is ca. 20) without more ado nevertheless they are orientating.

\section{References}

Andersen, S. T., De Vries, H. De., Zagwijn,W. H. (1960): 1960 Climatic changes and radiocarbon dating in the Weichselian Glacial of Denmark and The Netherlands. Geo, en Mijnbow. 39. pp. 38-42.

DÁvid L. (1992): A Mátra északi lejtöinek csuszamlásos felszínfejlödése. Fol. Hist.-nat.Mus. Matr. 17. pp 9-26.

KRIPPEL, E. (1986): Postglacialny vyvoj vegetácie Slovenska. p. 307. VEDA. Bratislava.

SZABO,. J. (1992): Landslide processes and forms in the Hungarian Moutains of volcanic origin. In: New perspectives in Hungarian geography - Studies in Geography in Hungary 27. Budapest. pp. 63-75.

- (1993): Vergleichende Untersuchung der Rutschungsprozesse in Ungarn. Berliner Geographische Arbeiten, Heft 79, Berlin. pp. $133-161$.

SzźkELY, A. (1983): Vergleichende vulkanische Mittelgebirgsforschung in Ungarn. Wissenschaftliche Kolloquien der ungarischen Wirtschafts- und Kulturtage in Hamburg. Hrsg. W. Bachofer, H. Fischer, München pp. 207-238.

SzÉkELY, A. (1987): Vulkáni hegységeink a legújabb kutatások tükrében. (The volcanic mountains of Hungary - in the light of recent research. Földrajzi Közl. 35/111) pp. 134-142.

Manuskript eingegangen am 11.03.96 